\section{Hyperlactatemia in patients without tissue hypoperfusion}

To the Editor: Fumio Kunimoto

Intensive Care Unit, Gunma University Hospital

(3-39-15, Showa-machi, Maebashi, Gunma 371-8511, Japan)
In Reply: Seiji Hida

Division of Emergency and Critical Care Medicine, Graduate School of Medicine and Dental Science, Niigata University (757, Ichibancho, Asahimachi-dohri, Niigata 951-8510, Japan)

J Jpn Soc Intensive Care Med. 2006;13:73 75 .

\title{
オーストラリアにおける集中治療専門医試験
}

1976 年，世界で初めて集中治療医の専門医試験が オーストラリアにて施行された。年に 2 回あるこの試 験は世界で最も古く, 洗練された集中治療専門医試験 だと評価されている。

私は 2005 年 5 月に施行されたこの専門医試験に合格 した。今後, 日本の集中治療を担う方々に何らかの参 考になればという目的で, 試験の内容, 合格へのポイ ントをかいつまんで紹介する。

\section{1. 日本人がオーストラリアの集中治療専門医 試験を受ける意義}

将来オーストラリアで過ごす意志がなくとも海外か ら受験に訪れる人々が多々存在するが, その理由は, こ の試験が世界で広く認められた高水準のものというこ とにある。私が知る限り, 少なくとも, シンガポール とアイルランドでは，自国に集中治療医専門医試験が あるにかかわらず，このオーストラリアの資格がそれ を上回るため，あらためて自国の試験を受ける必要がな w。

日本は「集中治療医」に対する認識が希薄である。最 近，集中治療医がclosed ICUを運営することによって 患者予後が改善したという報告が各国でなされている が，その「集中治療医」とは何なのか。それを知るに は自分がその集中治療医が存在する場所で集中治療医 になるというのが一番分かりやすいと考えた。

\section{Primary examination}

集中治療専門医試験（final examination）を受けるに は, 麻酔, 救急, 内科いずれかの primary examination に合格する必要がある。私のバックグラウンドは麻酔
科であるため，麻酔の primary を受験した。麻酔の primaryは physiology, pharmacology, statistics, physicsの試験である。筆記と口頭に分かれており，筆 記の合格後に口頭試験を受験する。Physiologyは麻酔 に関係なく全蔵器の physiology で; pharmacology, physics は麻酔，ICU 関連である。この試験には平均 1,000 時間の勉強時間が必要とされている。

日本の多くの医師にとって，この試験がFinalより難 しく感じられることであろう。日本の若い麻酔科医の 何人がミダゾラムの構造式を書き，それが水に溶ける とどう変化するかを知っているのだろうか。過去問題 の例を Table 1 に示す。過去問題は学会から出版され ているが，効率よくまとめられたものが internet 上で 手に入る (http://www.anaesthesiamcq.com/ default.htm)。筆記はmultiple choice questions と short answer questions に分かれており，後者は 1 問につき 10 分。制限時間を守って解く練習をする。

\section{Final examination}

筆記, OSCE (data interpretation, ECG, X-ray, CT, MRI, instrument, communication, procedure, etc.), VIVA, clinicalの4つに分かれている。

\section{1) 筆記}

1 問 10 分を 30 問 (午前と午後で 15 問ずつ)。幅広い 知識を必要とする。質問の答え方のポイントを紹介し よう。

たとえば，“Critically evaluate the role of nitric oxide in the management of the critically ill patient." $と$ いう質問は，時間さえあればこのタイトルで一つの論 文が書けてしまうくらいだが，10分以内に合格点を得 
Table 1 Primary Short Answer Questions の例

\begin{tabular}{|c|c|}
\hline Subject & \\
\hline \multirow[t]{7}{*}{ Physiology } & Describe the mechanism of action of G-proteins in the cell. \\
\hline & Explain the role of haemoglobin as a buffer. \\
\hline & $\begin{array}{l}\text { Draw a respiratory flow/volume loop and outline how it is obtained. Briefly explain the physiological } \\
\text { mechanisms involved in the concept of flow limitation. }\end{array}$ \\
\hline & $\begin{array}{l}\text { Describe how carbon dioxide is produced in the body. } \\
\text { How does it move from the site of production to the pulmonary capillary? }\end{array}$ \\
\hline & Describe the compensatory mechanisms in a fit person moving from the supine to the standing position. \\
\hline & Describe the functions of the loop of Henle, including the physiological mechanisms involved. \\
\hline & Explain the Bohr and Haldale effects in trans-placental gas exchange. \\
\hline Physics & Briefly explain how oximetry can be used to estimate the partial pressure of oxygen in a blood sample. \\
\hline \multirow[t]{6}{*}{ Pharmacology } & Outline the influences of pregnancy on pharmacokinetics. \\
\hline & $\begin{array}{l}\text { What is an isomer? Briefly write an account of the types of isomers and their significance in drugs used } \\
\text { in anaesthesia. }\end{array}$ \\
\hline & $\begin{array}{l}\text { Describe how a computer-controlled infusion device targets and maintains constant blood concentra- } \\
\text { tions of propofol. }\end{array}$ \\
\hline & Outline the effects of an opioid injected into the spinal intrathecal space. \\
\hline & Outline the pharmacology of oxytocin. \\
\hline & What are the side-effects of amiodarone and what problems may develop during concurrent anaesthesia? \\
\hline Statistics & $\begin{array}{l}\text { What is meant by ' } 95 \% \text { confidence interval'? Explain the practical applications of confidence intervals and } \\
\text { indicate why they may be preferred to P-values. }\end{array}$ \\
\hline
\end{tabular}

られる答えを書くには，このような質問（critically evaluate something)にはこう答えるといったformat を自分なりに作っておくことである。私の場合， definition, mechanism of action, how to use, clinical indication, advantage, disadvantage, discussion, conclusion という順序である。自分なりの決まり文句 を作っておくことも勧める。10分という短い時間内に 単語や文法を選んでいる暇はない。たとえば, “This is life threatening emergency situation. Prompt resuscitation (airway, breathing, circulation) with concurrent diagnostic approach is necessary.”といった具合であ る。

\section{2) OSCE}

日本からの受験者が比較的得意とする section と思わ れるが, communicationは英語が得意でない者にとっ て明らかに不利である。この試験では女優が患者の母 親，娘，妻に扮し，当惑したり泣いたりするのに対応 する。患者が脳死になったという設定はよく使われる。 脳死の他に, withdraw, futile treatmentの考え方は日 本と違うので知っておく必要がある。

\section{3) VIVA}

シナリオが戸に張ってあり，2 分間読む時間がある。 チャイムが鳴ると中に入り，10 分間の口頭試験が行わ

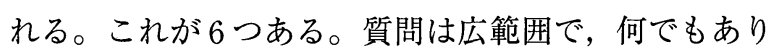
であるが, 筆記に合格する知識があれば十分である。後 は話す練習をできるだけ多くすることである。

\section{4) Clinical}

最も難しいのがこのclinical sessionである。 Hot case と cold case に分かれる。

(1) Hot case

実際にICU の患者を診察する。時間は 1 人の患者に つき20分。これを 2 セット行う。まず試験官が簡単な 患者の紹介をする。“This is 48 year-old Mr. Smith. He had collapsed 2 days ago and subsequently was admitted to this ICU. Please examine him generally, especially pay attention to cardiovascular system.”患 者に自己紹介をした後（たいていの場合，鎮静され反 応はないが)，全体を見回し，ベッド周りを見た後， head to toeの診察を行う。熟練した麻酔科医であれば, 麻酔の導入の際, 次に何をすると考えることなく, 自 
動的に手と体が動くことであろう。同様のsmoothさが この診察では求められる。診察はautomaticであるが, 頭の中では常に, 何がこの患者の主な問題点で, 鑑別 診断は何か，他にどんな問題点があるか等を考えてい なければならない。診察, presentation, discussionを 含めて20分であるため, ゆっくりしていると途中で診 察を遮られる。

Presentation は様々な情報を重箱の中にきれいにつ め試験官に差し出すような, 整った美しいものである ことが望ましい。毎日のように練習し, ある程度のパ ターンを作る。Presentation 後の最初の質問は多くの 場合, “You are the consultant of today. Tell me how to treat this patient. What is your plan?” である。こ のとき，試験官に自分と同じレベルの者と会話してい ると思わせるような堂々とした話し方, 態度が必要で ある。

Hot case は集中治療医としての臨床能力をみる大切 なセッションであり, すべての受験者にとって最も難 しいセッションとされている。州内の病院を回って各 病院のコンサルタントのもと, 練習を重ねる。

(2) Cold case

ICU以外の実際の患者を診察し所見を述べるもので， 麻酔科出身者にとっては難関である。制限時間は 10 分 で 2 症例与えられる。“48 year-old Ms A complaining difficulty of walking. Please examine her neurological system." " 59 year-old Mr. X with shortness of breath. Please examine his cardiovascular system."

診察はneurological system以外はすべて手から始ま る。すべてのシステムの診察にはルーチンがあり, 省 略してはならない (Talley and O'Connor の “Clinical Examination: a systematic guide to physical diagnosis" をほとんどの受験者が使用している)。手早く診察し, 正しく徵候を見つけ, 診断, 鑑別診断, 診断の重症度, 必要な情報, 検查を一気に述べられるよう練習する。何 らかの徴候がある患者の名前とそのシステムを内科医 に教えてもらい，時間を見つけてコンサルタントある いは他の受験者とストップウォッチを持って診察に行 く。Native English speakerでさえ presentation の練 習を, 家や車の中でも声に出して常に行っている。

\section{4. 最後に}

私は日本では数少ない, 完全 closed ICU で麻醉科, 救急, 内科のバックグラウンドを持つ集中治療医をめ ざす同僚と仕事をしていた。これは，オーストラリア に近い，日本では珍しいICUである。そこで自分が指 導する立場になるにつれ, 集中治療医とは何であるか 十分に理解していない者が次の集中治療医を育てるこ とはできないと感じた。このことが, 集中治療医を独 立した専門医として認識しているオーストラリアでト レーニングを受けようと思ったきっかけである。

英語を勉強に行ったわけではない。日本語で同様な トレーニングが受けられるのであれば，どんなに効率 が良いかと思う。次に続く者が多く現れ, いずれは自 国にて，他国に勝るとも劣ら婎中治療の教育システ ムが設立できることを望む。なぜなら，それが日本の 集中治療のさらなる発展の重要な基礎になると信じて いるからである。

これを読みオーストラリアでのトレーニングに興味 を持たれた方へ。日本の医師免許にて最長 5 年間の臨 床研修が可能である。職を得やすい状況にいる方, そ うでない方とあるだろうが, 思いつくすべての方法を 使い諦めなければ, 不可能なことはない。その苦労に 見合う以上のものが得られるであろう。

後藤 幸子

Intensive Care Unit, Sir Charles Gairdner Hospital

(Hospital Avenue, Nedlands, WA, 6009, Australia)

受付日 2005 年 7 月 5 日 採択日 2005 年 10 月 17 日

\section{Intensive Care Fellowship Examination in Australia}

\section{Yukiko Goto}

Intensive Care Unit, Sir Charles Gairdner Hospital (Hospital Avenue, Nedlands, WA, 6009, Australia)

J Jpn Soc Intensive Care Med. 2006;13:75 77 . 